Original Article

\title{
The application of ammonium sulphate and amino acid on cotton: effects on can improve growth, yield, quality and nitrogen absorption
}

\author{
Aplicação de sulfato de amônio e aminoácido no algodão: efeitos sobre o crescimento, \\ o rendimento, a qualidade e a absorção de nitrogênio
}

\author{
N. Hussain ${ }^{\mathrm{a}}$ (D) A. Yasmeen ${ }^{*}$ (1) and M. Bilala (D) \\ aBahauddin Zakariya University, Faculty of Agricultural Sciences and Technology, Department of Agronomy, Multan, Pakistan
}

\begin{abstract}
A field study was carried out to determine the influence of foliage applied plant growth promoter and retardant in improving soil applied sulphur fertilizer use efficiency in cotton during two consecutive summers 2014 and 2015. Experimental trial comprised of three different sources of sulphur (ammonium sulphate, potassium sulphate and elemental sulphur) and foliar spray of plant growth promoter and growth retardant including tap water was taken as control. Among treatments soil applied ammonium sulphate with foliage applied amino acid produced maximum plant height, sympodial branches, pods per plant, seed cotton yield, fiber yield, biological yield, protein contents, oil contents and leaf nitrogen uptake as compared to the other treatments. Whereas, soil applied potassium sulphate with foliar spray of mepiquat chloride on cotton significantly improved the boll weight and leaf potassium uptake. We conclude that soil applied ammonium sulphate and foliage spray of amino acid was more effective in improving the productivity and quality attributes of cotton.
\end{abstract}

Keywords: mepiquat chloride, seed protein, nutrients uptake, potassium sulphate, sulphur.

\begin{abstract}
Resumo
Foi realizado um estudo de campo para determinar a influência do promotor de crescimento das plantas e retardador da folhagem em algodão, para melhora da eficiência do uso de fertilizantes à base de enxofre aplicados no solo durante dois verões consecutivos (2014 e 2015). O ensaio experimental foi composto de três fontes diferentes de enxofre (sulfato de amônio, sulfato de potássio e enxofre elementar) e pulverização foliar do promotor de crescimento de plantas e retardador de crescimento, incluindo água da torneira que foi tomada como controle. Entre os tratamentos, o sulfato de amônio aplicado no solo com aminoácido aplicado na folhagem produziu o máximo na altura da planta, ramos simodiais, capulhos por planta, rendimento de algodão em caroço, rendimento de fibra, rendimento biológico, conteúdo de proteínas, conteúdo de óleo e absorção de nitrogênio nas folhas quando comparado a outros tratamentos. Enquanto o solo fertilizado com sulfato de potássio e aplicação foliar de cloreto de mepiquat no algodão melhorou, significativamente, o peso do capulho e a absorção de potássio nas folhas. Sulfato de amônio aplicado no solo e a aplicação foliar de aminoácidos foram mais eficazes na melhora dos atributos de produtividade e qualidade do algodão.
\end{abstract}

Palavras-chave: cloreto de mepiquat, proteína em sementes, absorção de nutrientes, sulfato de potássio, enxofre.

\section{Introduction}

Cotton (Gossypium hirsutum L.), the king of fibers, is a major cash crop, which is commercially grown for agricultural and industrial purposes (Iqbal et al., 2017). Cotton fiber in earlier times and its by-products nowadays has dominated the economy of developing and developed countries of the world as well. Cotton is an important agricultural commodity and occupies a distinctive position in the agriculture-based economy. It is the key source of employment for millions involved in production; processing, ginning, fabric and oil industry and trade related activities (Noreen et al., 2013).

Improvement in crop productivity with the adoption of high-yielding genotypes and multiple cropping systems, use of fertilizers has become more and more imperative to enhance the crops produce and quality. Sulphur is the fourth element essential for plant growth after nitrogen, phosphorus and potassium. It is indispensable for the synthesis of amino acids, proteins, oils, and stimulates enzyme system in the plants (Najafian and

*e-mail: azra.yasmeen@bzu.edu.pk

Received: June 26, 2020 - Accepted: November 23, 2020

This is an Open Access article distributed under the terms of the Creative Commons Attribution License, which permits unrestricted use, distribution, and reproduction in any medium, provided the original work is properly cited. 
Zahedifar, 2015). It is also an essential component of vitamin $A$, biotin and thiamine $\left(B_{1}\right)$ required for the plant to carry out its biochemical processes and an iron-sulphur protein occurring in the chloroplasts called ferredoxins (Scherer et al., 2008). Sulphur application reduced the soil $\mathrm{pH}$, which considerably improved the chlorophyll concentration, nutrient uptake and dry matter accumulation (Motior et al., 2011). The function of sulphur is to assist plants in the synthesis of proteins and chlorophyll and improves root growth. It also plays an active role in development and quality of cottonseed.

Besides plant essential nutrients, certain growth promoters have also improved the productivity and quality attributes of cotton (Arif et al., 2019). Among different growth promoters, amino acids are gaining a lot of consideration nowadays, which has encouraging influence on the plant growth and productivity (Kowalczyk and Zielony, 2008). Amino acids are organic molecules, comprised of nitrogen, hydrogen, oxygen and carbon, which have an organic side-chain in their structure that differentiates the distinctive amino acids (Buchanan et al., 2000). The principal amino acids produced by plants are the glutamine, aspartate and glutamate, and from these other amino acids may be synthesized. Glutamate is the major amino acid in which the nitrogen absorbed by the plants is incorporated and from it, a series of amino acids can be achieved with the aminotransferases activity (Taiz and Zeiger, 2013). They have encouraging influences on the physiological activities of growth and development in different plants and improved the productivity (Koukounaras et al., 2013; Sadak et al., 2015).

In addition to growth promoters, some plant growth retardants also play an important role in internal control mechanism of cotton plant growth by interacting with crucial metabolic activities like protein synthesis and nucleic acid. The most commonly used growth inhibitor in cotton is mepiquat chloride, which is inhibits the formation of gibberellic acid. It controls the undesired vegetative development, enhances the leaf thickness, decreases leaf area, shortens internodes and reduces the plant height, and hence consequences in a compact plant structure (Yasmeen et al., 2016). Adjustment in cotton plant architecture influences the light penetration into the canopy and improves the light interception in the middle part of the canopy and increases the light use efficiency that resulting in improved retention of bolls at lower sympodial branches and higher seed cotton yield along with reduced square and flowers abortion can stimulate early maturity (Nuti et al., 2006; Gonias et al., 2012).

Though numerous studies indicated the constructive roles of sulphur, amino acid and mepiquat chloride on cotton productivity but to best of our information no study has been carried out to explore the interactive effects of sulphur, amino acid and mepiquat chloride on growth, yield and quality attributes of cotton. Therefore, this study was planned to determine the influence of foliage applied plant growth promoter and growth retardant in improving the soil applied sulphur fertilizer use efficiency in cotton.

\section{Material and Methods}

A field study was carried to explore the influence of foliar application of plant growth promoter and retardant in improving the soil applied sulphur fertilizer use efficiency in cotton during two successive years 2014 and 2015. Experimental soil was silt clay loam having ECe 2.01 and $2.10 \mathrm{dS} \mathrm{m}^{-1}$, pH 7.95 and 8.08 , organic matter 0.58 and $0.53 \%$, total nitrogen 0.0052 and $0.0057 \%$, available phosphorus 6.2 and $6.7 \mathrm{ppm}$ and available potassium 270 and $245 \mathrm{ppm}$. Experimental trial comprised of three different sources of sulphur (ammonium sulphate, potassium sulphate and elemental sulphur) and foliar spray of plant growth promoter (glutamina amino acid $10 \mathrm{ppm}$ ) and growth retardant (mepiquat chloride $12 \mathrm{~g} \mathrm{ha}^{-1}$ a.i.) including control (tap water). Foliar spray of different treatments was applied 100 and 130 days after sowing. The field study was designed in a completely randomized block with factorial arrangement having three repeats.

\subsection{Crop husbandry}

Before land preparation for research activities, presoaking irrigation (Rauni) was applied. As the soil reached to a workable moisture level, a fine seedbed was prepared by cultivating the experimental plot thrice and then bed shaper was used for proper beds formation. Delinted seeds of FH-142 were manually sown during first week of April 2014 and 2015 by keeping $20 \mathrm{~cm}$ plant-to-plant distance. To ensure optimum plant population, each experimental unit was again irrigated two days after dibbling. Succeeding irrigations were applied according to crop requirements. Nitrogen fertilizer ( $\left.150 \mathrm{~kg} \mathrm{ha}^{-1}\right)$ was applied, in the form of Urea, at three unique growth periods i.e. at the time of sowing, start of bloom and peak flowering stage. However, complete dose of phosphorus (60 $\left.\mathrm{kg} \mathrm{ha}^{-1}\right)$ and potassium fertilizer $\left(65 \mathrm{~kg} \mathrm{ha}^{-1}\right)$ was applied in the form of SSP and SOP at the time of sowing, respectively. Pre-emergence herbicide was sprayed to control weeds along with threehand weeding at the $12^{\text {th }}, 21^{\text {st }}$ and $30^{\text {th }}$ days after sowing. Various plant protection measures were used to retain the cotton pests under the threshold level. All the agronomic practices excluding experimental treatments were kept identical for each experimental unit.

\subsection{Data collect}

After 35 days of sowing, fifteen plants were selected randomly in each experimental unit and tagged to record the data on various agronomic parameters through adopting standard procedures. Data regarding plant height from tagged plants of each plot were noted from the base to the tip of the main stem and averaged. Sympodial (fruit bearing) branches and number of bolls per plant from tagged plants of each experimental unit were counted and averaged. Mean boll weight was recorded from twenty bolls of tagged plants covering base to top in each picking and averaged. Similarly, seed cotton yield was picked three times from net plot of each experimental unit and weighed and then converted into kilograms per hectare. Moreover, fiber yield attained from selected area bolls of the each plot and weighed and then converted into kilograms per 
hectare. Biological yield was recorded from net plot of each plot was collected and weighed and then converted into kilograms per hectare.

To record oil contents, $3 \mathrm{~g}$ of the processed samples were weighed into a known weight of thimble. A clean dry extraction flask (250ml capacity) was weighed and sufficient quantity of $400 \mathrm{C}-600 \mathrm{c}$ acetone was poured into it. The thimble with the sample was placed into the flask and oil was extracted as already described above. At the end of extraction, the resulting mixture containing oil was heated to recover the solvent and the weight of the round bottom flask with oil was noted after cooling (Okonkwo and Okafor, 2016).

The crude protein was determined by Kjeldahl method. $2 \mathrm{~g}$ of processed sample were taken and placed into $100 \mathrm{ml}$ Kjeldahl digestion flasks. Few grams of Kjeldahl catalyst mixture $\left(\mathrm{Na}_{2} \mathrm{SO}_{4}+\mathrm{CuSO}_{4}\right)$ and $15 \mathrm{ml}$ of conc. $\mathrm{H}_{2} \mathrm{SO}_{4}$ were added. The mixtures were mixed thoroughly and heated in a fume cupboard for about 2 hours until complete digestion was reached. This was identified when a clear solution was obtained. The cool digest was diluted to $100 \mathrm{ml}$ and only $10 \mathrm{ml}$ of the digest was mixed with equal volume of $10 \mathrm{~mol} / \mathrm{dm}^{3} \mathrm{NaOH}$. The mixture was placed in micro-Kjeldahl distillation apparatus which was distilled by steam and the distillate was collected into a conical flask containing $10 \mathrm{ml}$ of $4 \%$ Boric acid. Few drops of mixed indicator (5g bromocrysol green and $1 \mathrm{~g}$ methyl red in $100 \mathrm{ml}$ of ethanol) were added into $50 \mathrm{ml}$ of the distillate and titrated against $0.1 \mathrm{M} \mathrm{H}_{2} \mathrm{SO}_{4}$ solution. A blank was conducted simultaneously under similar experimental condition (Okonkwo and Okafor, 2016).

Total nitrogen in organic material was estimated by Kjeldahl distillation method described by Jackson (1962). While, phosphorus was determined by spectrophotometer (Milton Roy Company) using the Barton reagent described by Ashraf et al. (1992). Potassium content in the filtrate was determined by Jenway PFP-7 flame photometer described by Richards (1954).

\subsection{Statistical analysis}

All the collected data was statistically analyzed by using the computed based software M STAT C. DMR test was used to compare variations among different treatment means at 5\% probability level (Steel et al., 1997).

\section{Results}

Application of plant growth promoters and retardant significantly affected the growth, yield and quality attributes of cotton. Results showed that interaction among different sources of sulphur and foliar spray of plant growth regulators significantly affected plant height during 2014 and 2015 (Table 1). Soil applied ammonium sulphate and foliar spray of amino acid produced significantly taller plants against the minimum height was recorded with the application of elemental sulphur with foliar spray of mepiquat chloride (Table 1). Likewise, sympodial branches also significantly improved by interactive influences of sulphur sources and foliar spray of plant growth regulators. Application of ammonium sulphate with foliar spray of amino acid produced maximum sympodial branches per plant. While the minimum sympodial branches were observed with the application of elemental sulphur with foliar spray of mepiquat chloride during both growing seasons (Table 1).

Bolls per plant of cotton crop is identified as a fundamental and foremost yield-determining constituent and contributes considerably to the final productivity. Results showed that interaction among sulphur sources and foliar spray of plant growth regulators significantly affected the bolls per plant during both growing season (Table 1). Application of ammonium sulphate with foliar spray of amino acid produced maximum bolls per plant. While soil applied elemental sulpur produced minimum number of bolls per plant from control plots (Table 1).

Interaction among sulphur sources and foliar application of plant growth regulators significantly affected the boll weight during 2014 and 2015 (Table 1). Application of potassium sulphate with foliar spray of mepiquat chloride produced significantly higher boll weight. While the minimum boll weight was recorded with the soil application of elemental sulphur from control plots (Table 1).

A numerous internal and external aspects control seed cotton yield and any discrepancy in them is responsible to bring modifications in yield. Application of sulphur fertilizer and foliar application of plant growth regulators significantly affected the seed cotton and fiber yield during both growing seasons (Table 2). However, application of ammonium sulphate with foliar spray of amino acid produced significantly higher seed cotton yield. While the minimum seed cotton and fiber yield was observed from control plots (Table 2).

Interaction among sulphur sources and foliar application of plant growth regulators significantly affected the biological yield during 2014 only (Table 2). Application of ammonium sulphate with foliar spray of amino acid produced significantly higher biological yield against the minimum was observed with the soil application of elemental sulphur and foliar spray of mepiquat chloride. Similarly, soil applied sulphur fertilizer and foliage applied growth regulators significantly affected the protein and oil contents during both growing seasons (Table 2 and 3 ). Application of ammonium sulphate with foliar spray of amino acid produced significantly higher protein and oil contents. While the minimum protein and oil contents was observed with the application of elemental sulphur from control plots (Table 2 and 3 ).

Interaction among sulphur sources and foliar application of plant growth regulators significantly affected the nitrogen contents during both growing seasons (Table 3 ). Application of ammonium sulphate with foliar spray of amino acid uptake maximum nitrogen contents. While the minimum leaf nitrogen contents was observed with the application of elemental sulphur from control plots (Table 3). However, application of sulphur fertilizer and growth regulators had insignificant effect on leaf phosphorus uptake during both growing seasons (Table 3 ).

Results showed that interaction between different sources of sulphur fertilizers and foliar application of plant growth regulators significantly affected the leaf potassium uptake during both growing seasons (Table 3 ). Application 
Table 1. Effect of sulphur sources and foliar spray of growth regulators on plant height $(\mathrm{cm})$, sympodial branches, pods per plant and mean boll weight $(\mathrm{g})$.

\begin{tabular}{|c|c|c|c|c|c|c|c|c|c|}
\hline & \multirow{3}{*}{$\begin{array}{l}\text { Foliar } \\
\text { spray }\end{array}$} & \multicolumn{4}{|c|}{2014} & \multicolumn{4}{|c|}{2015} \\
\hline & & \multicolumn{4}{|c|}{ Sources of sulphur } & \multicolumn{4}{|c|}{ Sources of sulphur } \\
\hline & & $\begin{array}{l}\text { Ammonium } \\
\text { Sulphate }\end{array}$ & $\begin{array}{c}\text { Potassium } \\
\text { Sulphate }\end{array}$ & $\begin{array}{l}\text { Elemental } \\
\text { Sulphur }\end{array}$ & Mean & $\begin{array}{l}\text { Ammonium } \\
\text { Sulphate }\end{array}$ & $\begin{array}{l}\text { Potassium } \\
\text { Sulphate }\end{array}$ & $\begin{array}{l}\text { Elemental } \\
\text { Sulphur }\end{array}$ & Mean \\
\hline \multirow{6}{*}{$\begin{array}{c}\text { Plant } \\
\text { height } \\
(\mathrm{cm})\end{array}$} & Control & 146.28ab & 141.01b & $135.40 \mathrm{bc}$ & 140.90B & 143.95ab & 144.35ab & $141.40 \mathrm{bc}$ & 143.23B \\
\hline & $\begin{array}{l}\text { Amino } \\
\text { Acid }\end{array}$ & $155.85 a$ & $149.21 \mathrm{ab}$ & $143.32 \mathrm{ab}$ & $149.46 \mathrm{~A}$ & 157.19a & $151.54 \mathrm{ab}$ & $147.32 \mathrm{ab}$ & $152.02 \mathrm{~A}$ \\
\hline & $\begin{array}{c}\text { Mepiquat } \\
\text { Chloride }\end{array}$ & $126.06 \mathrm{c}$ & $124.86 c$ & $122.98 \mathrm{c}$ & $124.63 \mathrm{C}$ & $128.39 \mathrm{~cd}$ & 123.19d & $120.31 d$ & 123.97C \\
\hline & Mean & $142.73 \mathrm{~A}$ & $138.36 \mathrm{AB}$ & 133.90B & & $143.18 \mathrm{~ns}$ & 139.69 & 136.34 & \\
\hline & $\begin{array}{c}\text { LSD } \\
0.05 p=\end{array}$ & \multicolumn{4}{|c|}{$\begin{array}{l}\text { Sulphur sources } 8.3026 \text {, Foliar spray } 8.3026 \text {, } \\
\text { Interaction } 14.381\end{array}$} & \multicolumn{4}{|c|}{$\begin{array}{l}\text { Sulphur sources ns, Foliar spray } 7.8017 \text {, } \\
\text { Interaction } 13.513\end{array}$} \\
\hline & Control & 14.04ab & $12.91 \mathrm{bd}$ & $11.72 \mathrm{~cd}$ & $12.89 \mathrm{~A}$ & $13.37 \mathrm{bc}$ & 13.0bd & 12.09ce & $12.83 \mathrm{~B}$ \\
\hline \multirow{5}{*}{$\begin{array}{c}\text { Sympodial } \\
\text { branches } \\
\text { per plant }\end{array}$} & $\begin{array}{l}\text { Amino } \\
\text { Acid }\end{array}$ & $15.41 \mathrm{a}$ & $13.95 \mathrm{ac}$ & $11.97 \mathrm{bd}$ & $13.77 \mathrm{~A}$ & $15.08 \mathrm{a}$ & 14.45ab & $12.80 \mathrm{bd}$ & $14.11 \mathrm{~A}$ \\
\hline & $\begin{array}{c}\text { Mepiquat } \\
\text { Chloride }\end{array}$ & $12.02 \mathrm{bd}$ & $11.30 d$ & $11.04 d$ & $11.46 \mathrm{~B}$ & 12.49ce & 11.63de & $11.04 \mathrm{e}$ & $11.72 \mathrm{C}$ \\
\hline & Mean & $13.82 \mathrm{~A}$ & $12.72 \mathrm{AB}$ & $11.58 \mathrm{~B}$ & & $13.65 \mathrm{~A}$ & $13.04 \mathrm{~A}$ & $11.98 \mathrm{~B}$ & \\
\hline & $\begin{array}{c}\text { LSD } \\
0.05 p=\end{array}$ & \multicolumn{4}{|c|}{$\begin{array}{l}\text { Sulphur sources } 1.2918 \text {, Foliar spray } 1.2918 \text {, } \\
\text { Interaction } 2.2375\end{array}$} & \multicolumn{4}{|c|}{$\begin{array}{c}\text { Sulphur sources } 0.9778 \text {, Foliar spray } 0.9778 \text {, } \\
\text { Interaction } 1.6936\end{array}$} \\
\hline & Control & $24.54 \mathrm{ab}$ & 23.88ab & $21.02 b$ & $23.15 B$ & $22.77 b c$ & $22.88 b c$ & $21.72 \mathrm{c}$ & $22.46 \mathrm{~B}$ \\
\hline \multirow{6}{*}{$\begin{array}{c}\text { No. of } \\
\text { bolls per } \\
\text { plant }\end{array}$} & $\begin{array}{c}\text { Amino } \\
\text { Acid }\end{array}$ & $27.18 \mathrm{a}$ & $26.33 a$ & 24.87ab & $26.13 \mathrm{~A}$ & $28.35 a$ & 24.49ab & $24.90 \mathrm{ac}$ & $25.58 \mathrm{~A}$ \\
\hline & $\begin{array}{c}\text { Mepiquat } \\
\text { Chloride }\end{array}$ & $24.60 \mathrm{ab}$ & $24.83 a b$ & $21.97 \mathrm{~b}$ & $23.80 \mathrm{AB}$ & $24.80 \mathrm{ac}$ & $25.20 \mathrm{ac}$ & $23.97 \mathrm{bc}$ & $24.66 \mathrm{AB}$ \\
\hline & Mean & $25.44 \mathrm{~A}$ & $25.01 \mathrm{~A}$ & $22.62 \mathrm{~B}$ & & $25.31 \mathrm{~ns}$ & 24.86 & 23.53 & \\
\hline & $\begin{array}{c}\text { LSD } \\
0.05 p=\end{array}$ & \multicolumn{4}{|c|}{$\begin{array}{c}\text { Sulphur sources } 2.3322 \text {, Foliar spray } 2.3322 \text {, } \\
\text { Interaction } 4.0395\end{array}$} & \multicolumn{4}{|c|}{$\begin{array}{l}\text { Sulphur sources ns, Foliar spray } 2.4772 \text {, } \\
\text { Interaction } 4.2906\end{array}$} \\
\hline & Control & 3.36ab & $3.43 a$ & $3.29 b$ & $3.36 \mathrm{~B}$ & $3.26 \mathrm{c}$ & 3.36ab & $3.26 c$ & $3.29 \mathrm{~B}$ \\
\hline & $\begin{array}{l}\text { Amino } \\
\text { Acid }\end{array}$ & 3.38ab & $3.47 \mathrm{a}$ & 3.37ab & $3.41 \mathrm{AB}$ & $3.33 \mathrm{bc}$ & $3.40 \mathrm{ab}$ & $3.32 \mathrm{bc}$ & $3.35 \mathrm{~A}$ \\
\hline \multirow[t]{3}{*}{$\begin{array}{l}\text { Mean boll } \\
\text { weight }(\mathrm{g})\end{array}$} & $\begin{array}{c}\text { Mepiquat } \\
\text { Chloride }\end{array}$ & $3.43 a$ & $3.47 \mathrm{a}$ & $3.41 \mathrm{a}$ & $3.44 \mathrm{~A}$ & $3.36 \mathrm{ab}$ & $3.43 a$ & $3.35 \mathrm{ac}$ & $3.38 \mathrm{~A}$ \\
\hline & Mean & $3.39 \mathrm{~B}$ & $3.46 \mathrm{~A}$ & $3.36 \mathrm{~B}$ & & $3.31 \mathrm{~B}$ & $3.40 \mathrm{~A}$ & $3.31 \mathrm{~B}$ & \\
\hline & $\begin{array}{c}\text { LSD } \\
0.05 p=\end{array}$ & \multicolumn{4}{|c|}{$\begin{array}{c}\text { Sulphur sources } 0.0663 \text {, Foliar spray } 0.0663 \text {, } \\
\text { Interaction } 0.1148\end{array}$} & \multicolumn{4}{|c|}{$\begin{array}{l}\text { Sulphur sources } 0.0527 \text {, Foliar spray } 0.0527 \text {, } \\
\text { Interaction } 0.0914\end{array}$} \\
\hline
\end{tabular}

Means followed by same letter(s) are not significantly different at $\mathrm{P}<0.05$. LSD= Least significant difference.

of potassium sulphate with foliar spray of mepiquat chloride produced significantly higher potassium contents against the minimum was observed with the soil application of elemental sulphur from control plots.

\section{Discussion}

Plant growth promoters and retardants play dynamic roles in controlling the cotton plants growth, development and improved the final productivity (Yasmeen et al., 2016). In present study, soil application of ammonium sulphate with foliar spray of amino acid on cotton plants produced significantly taller plants. Whereas, minimum plant height was observed with the soil application of elemental sulphur and foliar spray of mepiquat chloride. Significantly higher plant height with ammonium sulphate and foliar spray of amino acid might be due to the fact that it contributes to the production of growth hormones that improved the cell division and cell enlargement (Sadak et al., 2015). These findings was also confirmed by Hammad and Ali (2014) they also reported that foliar spray of amino acid on crop plants can in enhance the chlorophyll contents, hence increased the photosynthetic rate that improves plant metabolism and protein assimilation which are necessary for cell formation and as a result improved the plant height. Likewise it was also reported that taller plants with the application of amino acid might be due to the biosynthesis of gibberellins (Shekari and Javanmardi, 2017). On the other 
Table 2. Effect of sulphur sources and foliar spray of growth regulators on seed cotton yield $\left(\mathrm{Kg} \mathrm{ha}^{-1}\right)$, fiber yield $\left(\mathrm{Kg} \mathrm{ha}^{-1}\right)$, biological yield $\left(\mathrm{Kg} \mathrm{ha}^{-1}\right)$ and protein contents (\%).

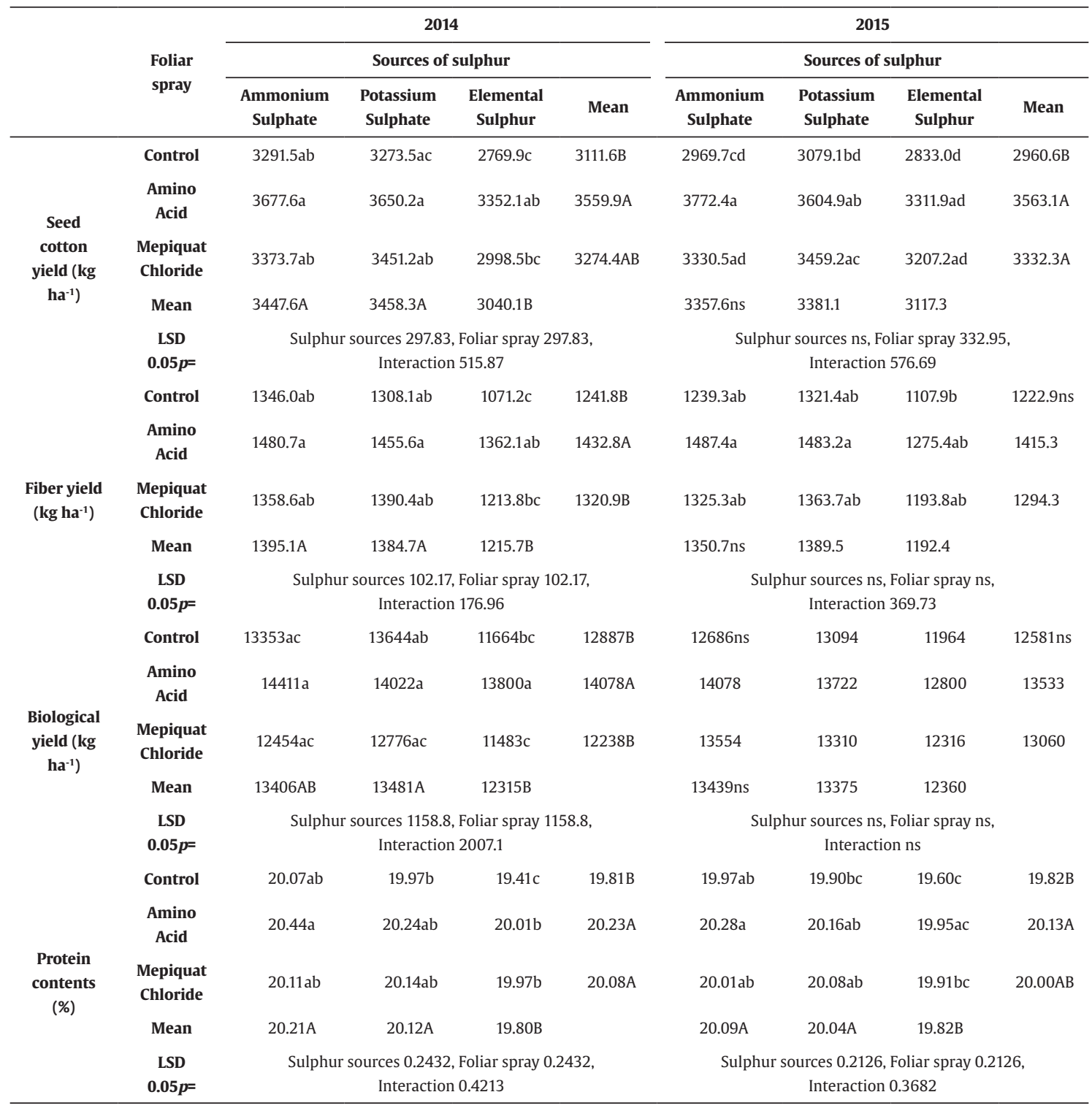

Means followed by same letter(s) are not significantly different at $\mathrm{P}<0.05$. LSD= Least significant difference.

hand, foliar spray of mepiquat chloride reduced the plant growth parameters. This decline in growth attributes is might be due to reduction of gibberellic acid concentration in plant cells, which causes hardening of the cell wall and reduced flexibility, which inhibited the extension and reproduction ability of the cells (Wang et al., 2014).

Higher number of reproductive / sympodial branches with the use of ammonium sulphate and amino acid might be credited to the higher photosynthetic rate and the absorption of mineral nutrients and they play a key role in secondary metabolism in cotton plants (Hildebrandt et al., 2015; Sadak et al., 2015). While, application of mepiquat chloride significantly reduced the sympodial branches might be due to the reduction of gibberellic acid that decreases the overall vegetative growth and therefore improves the reproductive structures by letting plants to translocate additional energy towards the reproductive structure (Yasmeen et al., 2016).

Application of potassium sulphate with foliar spray of mepiquat chloride produced significantly higher boll weight, which might be due to the fact that it modifies the source-sink relationship while restricting the vegetative growth and improved reproductive growth by allowing the cotton plants to translocate more photosynthates towards the reproductive organs and demonstrating the bolls on treated plants as larger sink for photosynthates (Yasmeen et al., 2016; Xiao et al., 2016). Whereas, it was also observed that application of ammonium sulphate with foliar spray of amino acid produced significantly higher number of bolls per plant, which ultimately 
Table 3. Effect of sulphur sources and foliar spray of growth regulators on oil contents (\%), nitrogen uptake (\%), phosphorus uptake (\%) and potassium uptake (\%).

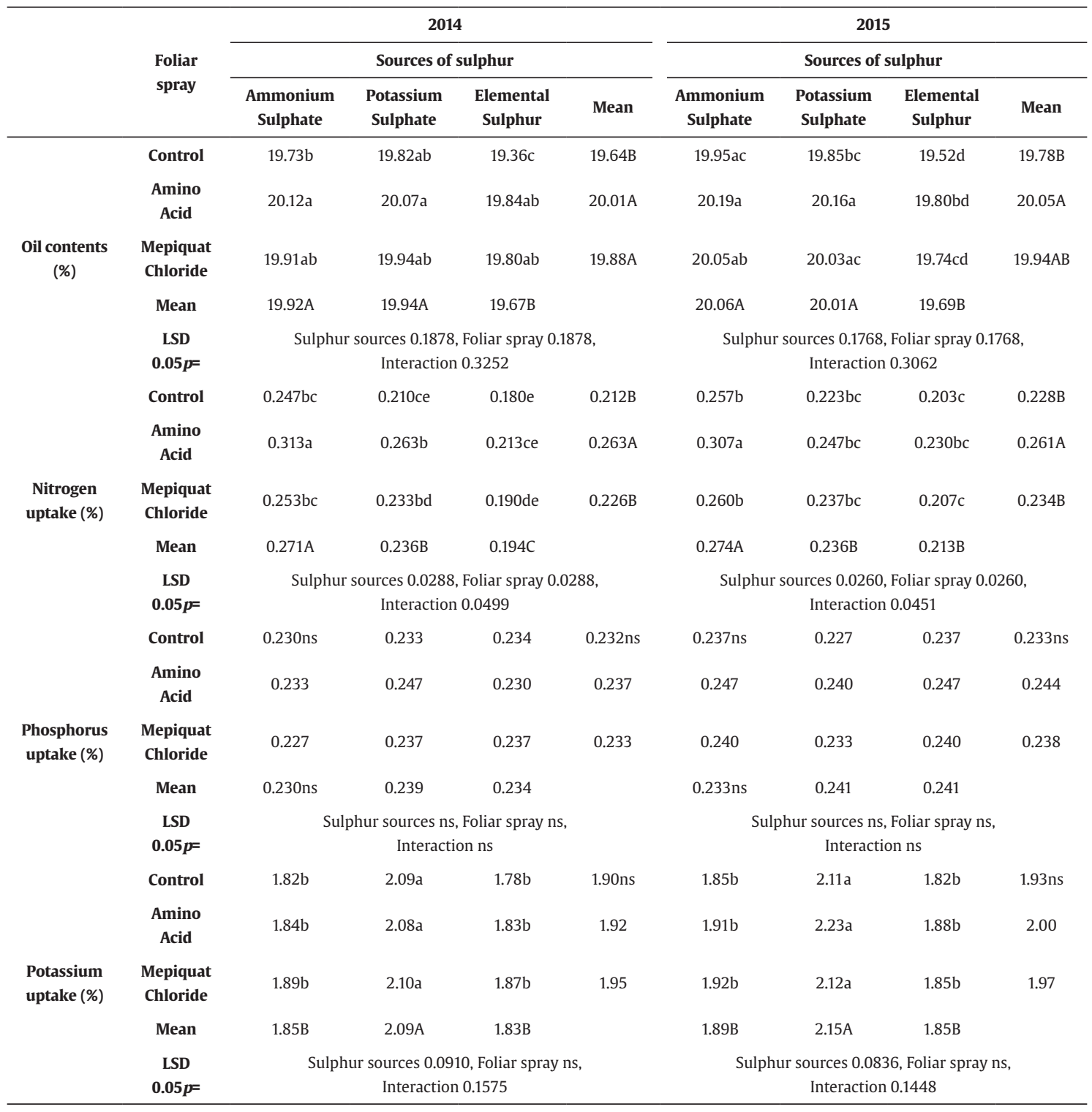

Means followed by same letter(s) are not significantly different at $\mathrm{P}<0.05$. LSD $=$ Least significant difference.

increased the seed cotton yield, fiber yield and biological yield. Soil application of ammonium sulphate and foliar spray of amino acids supply the cotton plant cells with an instantly accessible nitrogen source that usually can be taken by the cells more quickly than inorganic nitrogen. Availability of soluble sulphur liberates more sulphate ions into the soil solution ensuing in higher absorption of sulphur nutrients. This would have improved the metabolic activities and sustained the photosynthesis activities in the cotton plants and encouraged the meristematic process instigating improved dry matter synthesis due to appropriate partitioning of photosynthates from sources to sink (Braun et al., 2014). The influence of amino acids on crop physiology intensively studied and the principal attitude is that amino acids play the role of stimulates internal hormones production and facilitates the uptake of mineral nutrients (Gomes, 2019). Its foliar spray improved the photosynthetic pigments and as a result the effectiveness of the photosynthetic apparatus was boosted, which in turn substantially improved the sympodial branches, number of harvestable bolls per plant, seed cotton yield, fiber yield and ultimately biological yield per unit area (Sadak et al., 2015). It has direct influence on cotton plants involved modulation of nitrogen uptake and assimilation by the regulation of enzymes included in nitrogen assimilation and of their structural genes and by working on the signaling pathway of nitrogen absorption in roots. Modification in plant physiological and biochemical processes led to a higher yield and yield contributing attributes (Aksona and Unay, 2019). 
Application of ammonium sulphate with foliar spray of amino acid produced significantly higher oil and protein contents. In this respect, the improvement in oil and protein contents with different applied treatments are measured as a direct influence of higher minerals uptake that enhanced the photosynthesis rate and translocate photo-assimilates from leaves to cotton seed. Likewise, Hammad and Ali (2014) and El-Ghareib et al. (2014) observed that exogenous application of amino acid produced significantly higher protein content and attributed to its role in protein synthesis through enhanced conversion of amino acids in to protein. While, the improvement in oil content with the application of amino acid might be credited to enhanced assimilation and translocation of photosynthates (Zheljazkov et al., 2009; Mohammadi and Rokhzadi, 2012).

Application of one nutrient can affect mobility of other nutrient in soils, its uptake by plant roots and its metabolism in plant tissues. In present study, soil application of ammonium sulphate with foliar spray of amino acid uptake significantly higher nitrogen content. While soil application of potassium sulphate with foliar spray of mepiquat chloride uptake maximum potassium content. Improvement in nutrients uptake might be due to improved root growth, carbon dioxide assimilation and photosynthetic rate, and assimilate partitioning (Gwathmey and Clement, 2010). These results were confirmed in earlier studies by Liu et al. (2008) they concluded that improvement in mineral content showed the encouraging influence of the foliar spray by offering the plant cells adequate amount of nutrients and improving their uptake by roots and their accumulation and translocation in leaves. Similar results were reported by Sawan (2013) he observed that nitrogen and potassium contents improved in cotton plants with the application of mepiquat chloride.

\section{Conclusion}

We conclude that soil applied ammonium sulphate with foliage applied amino acid was more effective to improve the yield, quality and fertilizer use efficiency in cotton as compared to the other treatments.

\section{References}

AKSONA, G. and UNAY, A., 2019. The Effects of foliar applied atonik and amino acid on yield and fiber quality in cotton (Gossypium hirsutum L.). Adnan Menderes University Faculty of Agriculture Journal, vol. 16, pp. 81-84.

ARIF, M., HUSSAIN, N. and YASMEEN, A., 2019. Influence of bio-stimulant and potassium sources on the productivity of cotton. The Journal of Animal and Plant Sciences, vol. 29, no. 6 , pp. 1643-1653.

ASHRAF, M.Y., KHAN, A.H. and AZMI, A.R., 1992. Cell membrane stability and its relation with some physiological process of wheat. Acta Agronomica Hungarica, vol. 41, pp. 183-191.

BRAUN, D.M., WANG, L. and RUAN, Y.L., 2014. Understanding and manipulating sucrose phloem loading, unloading, metabolism, and signaling to enhance crop yield and food security. Journal of Experimental Botany, vol. 65, no. 7, pp. 1713-1735. http:// dx.doi.org/10.1093/jxb/ert416. PMid:24347463.
BUCHANAN, B.B., GRUISSEM, W. and JONES, R.L., 2000. Biochemistry and molecular biology of plants. Rockville, MD: American Society of Plant physiologists.

EL-GHAREIB, E.A., EL-SAYED, M.A., MESBAH, E.E. and AZZAM, K.A., 2014. Effect of foliar spraying with dolfan and zinc on yield and yield components of maize (Zea mays L.) under different nitrogen fertilizer rates. The Middle East Journal, vol. 3, pp. 465-471.

GOMES, T.F., 2019 [viewed 22 January 2010]. Amino acid technology contributes to cotton yield increase [online]. Available from: http://ag.alltech.com/en/blog

GONIAS, E.D., OOSTERHUIS, D.M. and BIBI, A.C., 2012. Cotton radiation use efficiency response to plant growth regulators. Journal of Agricultural Sciences, vol. 150, pp. 595-602.

GWATHMEY, C.O. and CLEMENT, J.D., 2010. Alteration of cotton source-sink relations with plant population density and mepiquat chloride. Field Crops Research, vol. 116, no. 1-2, pp. 101-107. http://dx.doi.org/10.1016/j.fcr.2009.11.019.

HAMMAD, S.A. and ALI, O.A., 2014. Physiological and biochemical studies on drought tolerance of wheat plants by application of amino acids and yeast extract. Annals of Agricultural Science, vol. 59, no. 1, pp. 133-145. http://dx.doi.org/10.1016/j. aoas.2014.06.018.

HILDEBRANDT, T.M., NUNES-NESI, A., ARAÚJO, W.L. and BRAUN, H.P., 2015. Amino acid catabolism in plants. Molecular Plant, vol. 8, no. 11, pp. 1563-1579. http://dx.doi.org/10.1016/j. molp.2015.09.005. PMid:26384576.

IQBAL, M., UL-ALLAH, S., NAEEM, M., IJAZ, M., SATTAR, A. and SHER, A., 2017. Response of cotton genotypes to water and heat stress: from field to genes. Euphytica, vol. 213, no. 6, pp. 131. http:// dx.doi.org/10.1007/s10681-017-1916-2.

JACKSON, M.L., 1962. Soil chemical analysis. Englewood Cliffs: Printce Hall Inc.

KOUKOUNARAS, A., TSOUVALTZIS, P. and SIOMOS, A.S., 2013. Effect of root and foliar application of amino acids on the growth and yield of greenhouse tomato in different fertilization levels. Journal of Food Agriculture and Environment, vol. 11, pp. 644-648.

KOWALCZYK, K. and ZIELONY, T., 2008. Effect of Aminoplant and Asahi on yield and quality of lettuce grown on rockwool. In: $\mathrm{H}$. GAWROŃSKA, ed. Biostimulators in modern agriculture. General aspects. Warszawa: Wieś Jutra, 89 p.

LIU, X.Q., KO, K.Y., KIM, S.H. and LEE, K.S., 2008. Effect of amino acid fertilization on nitrate assimilation of leafy radish and soil chemical properties in high nitrate soil. Communications in Soil Science and Plant Analysis, vol. 39, no. 1-2, pp. 269-281. http://dx.doi.org/10.1080/00103620701759301.

MOHAMMADI, K. and ROKHZADI, A., 2012. An integrated fertilization system of canola (Brassica napus L.) production under different crop rotations. Industrial Crops and Products, vol. 37, no. 1, pp. 264-269. http://dx.doi.org/10.1016/j.indcrop.2011.12.023.

MOTIOR, M.R., ABDOU, A.S., DARWISH, F.H.A., EL-TARABILY, K.A., AWAD, M.A., GOLAM, F. and SOFIAN-AZIRUN, M., 2011. Influence of elemental sulfur on nutrient uptake, yield and quality of cucumber grown in sandy calcareous soil. Australian Journal of Crop Science, vol. 5, no. 12, pp. 1610-1615.

NAJAFIAN, S. and ZAHEDIFAR, M., 2015. Antioxidant activity and essential oil composition of Satureja hortensis L. as influenced by sulfur fertilizer. Journal of the Science of Food and Agriculture, vol. 95, no. 12, pp. 2404-2408. http://dx.doi.org/10.1002/ jsfa.6959. PMid:25315247.

NOREEN, S., ATHAR, H.U.R. and ASHRAF, M., 2013. Interactive effects of watering regimes and exogenously applied osmoprotectants on earliness indices and leaf area index in cotton (Gossypium 
hirsutum L.) Crop. Pakistan Journal of Botany, vol. 45, pp. 1873-1881.

NUTI, R.C., VIATOR, R.P., CASTEEL, S.N., EDMISTEN, K.L. and WELLS, R., 2006. Effect of planting date, mepiquat chloride, and glyphosate application to glyphosate-resistant cotton. Agronomy Journal, vol. 98, no. 6, pp. 1627-1633. http://dx.doi. org/10.2134/agronj2005.0360.

OKONKWO, S.I. and OKAFOR, E.C., 2016. Determination of the proximate composition, physicochemical analysis and characterization of fatty acid on the seed and oil of Gossypium Hirsutum. International Journal of Chemistry, vol. 8, no. 3, pp. 57-61. http://dx.doi.org/10.5539/ijc.v8n3p57.

RICHARDS, L.A., 1954. Diagnosis and improvement of saline and alkali soils. USA: Soil and water Conservation Research Branch, Agricultural Research Service. United States Salinity Laboratory Staff. http://dx.doi.org/10.1097/00010694-195408000-00012.

SADAK, M.S.H., ABDELHAMID, M.T. and SCHMIDHALTER, U., 2015. Effect of foliar application of amino acids on plant yield and some physiological parameters in bean plants irrigated with seawater. Acta Biologica Colombiana, vol. 20, pp. 141-152.

SAWAN, Z.M., 2013. Plant growth retardants, plant nutrients, and cotton production. Communications in Soil Science and Plant Analysis, vol. 44, no. 8, pp. 1353-1398. http://dx.doi.org/10.10 80/00103624.2012.756509.

SCHERER, H.W., PACYNA, S., SPOTH, K.R. and SCHULZ, M., 2008. Low levels of ferredoxin, ATP, and leghemoglobin contribute to limited N2 fixation of peas (Pisum sativum L.) and alfalfa (Medicago sativa L.) under S deficiency conditions. Biology and Fertility of Soils, vol. 44, no. 7, pp. 909-916. http://dx.doi. org/10.1007/s00374-008-0273-7.
SHEKARI, G. and JAVANMARDI, J., 2017. Effects of Foliar Application Pure Amino Acid and Amino Acid Containing Fertilizer on Broccoli (Brassica oleracea L. var. italica) Transplant. Advances in Crop Sciences and Technology, vol. 5, no. 3, pp. 1-4. http:// dx.doi.org/10.4172/2329-8863.1000280.

STEEL, R.G.D., TORRIE, J.H. and DEEKEY, D.A., 1997. Principles and procedures of Statistics. A biometrical approach. 3rd ed. New York: Mc Graw Hill Book. Int. Co., pp. 400-428.

TAIZ, L. and ZEIGER, E., 2013. Plant physiology. 5th ed. Sunderland: Sinauer Associates, $782 \mathrm{p}$.

WANG, L., MU, C., DU, M., CHEN, Y., TIAN, X., ZHANG, M. and LI, Z., 2014. The effect of mepiquat chloride on elongation of cotton (Gossypium hirsutum L.) internode is associated with low concentration of gibberellic acid. Plant Science, vol. 225, pp. 15-23. http://dx.doi.org/10.1016/j.plantsci.2014.05.005. PMid:25017155.

XIAO, G.H., WANG, K., HUANG, G. and ZHU, Y.X., 2016. Genomescale analysis of the cotton KCS gene family revealed a binary mode of action for gibberellin A regulated fiber growth. Journal of Integrative Plant Biology, vol. 58, no. 6, pp. 577-589. http:// dx.doi.org/10.1111/jipb.12429. PMid:26399709.

YASMEEN, A., ARIF, M., HUSSAIN, N., MALIK, W. and QADIR, I., 2016. Morphological, growth and yield response of cotton to exogenous application of natural growth promoter and synthetic growth retardant. International Journal of Agriculture and Biology, vol. 18, no. 6, pp. 1109-1121. http://dx.doi.org/10.17957/IJAB/15.0213.

ZHELJAZKOV, V., CERVEN, V., CANTRELL, C., EBELHAR, M.W. and HORGAN, T., 2009. Effect of nitrogen, location, and harvesting stage on peppermint productivity, oil content, and oil composition. HortScience, vol. 44, no. 5, pp. 1267-1270. http:// dx.doi.org/10.21273/HORTSCI.44.5.1267. 